\title{
Institutional Transformations and Assessment of Profitability of the Interregional Distribution Grid Companies' Activity
}

\author{
Madina Valentinovna Alikaeva ${ }^{1}$ \\ Natalya Nikolaevna Novoselova2 \\ Bella Valeryanovna Kaziyeva ${ }^{1}$ \\ Rita Vanoevna Gurfova ${ }^{1}$ \\ Lidiya Zalim-Geriyevna Kerefova ${ }^{1}$ \\ ${ }^{1}$ Kabardino-Balkarian state university of H.M. Berbekov \\ ${ }^{2}$ North Caucasian federal universityRussian Federation; Email: nnn-nauka@yandex.ru
}

Doi:10.5901/mjss.2015.v6n5s3p331

\begin{abstract}
In article the factorial model of an assessment of assets profitability of the interregional distribution grid company including four factors characterizing financial, operational and investment efficiency of activity of the organization is developed and offered. The factorial analysis of assets profitability of JSC IDGC North Caucasus and JSC Chechen-Energo on the basis of the offered factorial model is carried out, conclusions and offers on activity efficiency increase of the studied organizations are made. The results of the present study may conduse to promoting the expansion of theoretical and methodological base of the financial and economic activity analysis for the energy network companies.
\end{abstract}

Keywords: factorial analysis, efficiency, profitability, interregional distribution grid company.

\section{Introduction}

Institutional transformations in power branch which main objective is increasing its competitiveness, ensuring reliability of power supply and energy security, entailed change of conditions of environment, business relationship between the power organizations and other subjects of economy. Now the given branch is characterized by the increased risks and threats of social and economic, political, ecological bases - therefore, in particular, there is a need of the solution of a number of the organizational and financial problems constraining its effective development. In this regard there is a need of development of a new approaches, strategy and methods of an assessment of performance efficiency of the inbterregional distribution grid companies (IDGC), providing delivery and transfer of the electric power.

\section{Main Part}

We suggest to use a technique of the determined factorial analysis in an assessment of profitability of the distribution grid company's activity as it allows rather economic means to establish relationships of cause and effect between indicators, to estimate and quantitatively measure influence of the separate areas of the organization's work on its overall economic efficiency.

As a key indicator it is offered to use the relation of size of net profit to the cumulative capital advanced in the organization`s activity (assets profitability on net profit, Rakt). This indicator reflects return level for each ruble (Russian currency) of investments made in the organization. The developed and offered factorial model estimates influence on an indicator of assets profitability of an interregional distributive network company of the most significant factors connecting its production, financial investment activity (table 1). 
Table 1 - Interrelation of a productive indicator of profitability of the IDGC assets and factors characterizing efficiency of production, financial and investment activity

\begin{tabular}{|c|c|c|c|}
\hline $\begin{array}{l}\text { Productive indicator }(\mathrm{Y}) \\
\text { Net profit (p. } 2400 \text { of the report on } \\
\left.\text { financial results }{ }^{1}\right) / \text { Balance result ( } p \text {. } \\
1700 \text { balances) }\end{array}$ & $\begin{array}{l}\text { Activities } \\
\text { the financial } \\
\text { Factor } \mathbf{X}_{1} \\
\text { Net profit/ Balance result } \\
\text { (p. } 1700 \text { balances) } \\
\text { The balancing } \\
\text { coefficient } a_{1}\end{array}$ & $\begin{array}{l}\text { the production } \\
\text { Factor } \mathbf{X}_{2} \\
\text { Net profit (p. } 2400 \text { of the report on financial } \\
\text { results) / Revenue (p. } 2110 \text { of the report on } \\
\text { financial results) }\end{array}$ & $\begin{array}{l}\text { the investment } \\
\text { Factor } \mathbf{X}_{3} \\
\text { Authorized capital ( } p \text {. } \\
1310 \text { balances) / Net } \\
\text { assets }\end{array}$ \\
\hline
\end{tabular}

1 - on the basis of the reporting indicators made according to Russian accounting standards.

2Thus, the factorial model of an assessment of profitability of the interregional distribution grid company (IDGC) assets has an appearance:

$$
y=X_{1} \times X_{2} \times X_{3} \times a_{1}
$$

where $Y$ - productive indicator (profitability of assets, certain on net profit),

$X_{1}$ the factor characterizing efficiency of financial activity of the organization,

$X_{2}$ - the factor characterizing efficiency of production (operational) activity of the company,

$X_{3}$ - the factor characterizing efficiency of investment activity of the organization,

$a_{1}$ - the balancing indicator.

The first factor $\left(X_{1}\right)$ reflects structure of the capital of the company and characterizes degree of independence of financial activity of loan sources of financing. It represents the modified coefficient of a financial autonomy (Kavt.mod), in which in numerator instead of a result according to the section "Capital and Reserves" of balance of the organization an net assets index has been used. The size of the organization's net assets characterizes existence of the assets which aren't burdened with obligations.

The factor of $X_{1}$ defines potential opportunity to influence financial policy of the company by change of structure and volume of the capital and obligations. The increase in value of this factor is a positive tendency that testifies to optimization of the structure (Magsumov, 2014) of own financing sources of the organization activity.

The second factor $\left(\mathrm{X}_{2}\right)$ represents the modified indicator of profitability of sales (Rprod.mod) and characterizes the size of net profit received by the organization for a certain period, in the ratio with the size of its revenue. In the conditions of the competitive energy market this indicator allows to estimate efficiency of IDGC market policy, the interrelation of its production and commercial activity is the most important indicator of its financial wellbeing. The higher the profitability of sales is in comparison to the last period (value of an indicator of the competing energy company, with the average size of an indicator in branch), the less the proceeds from sales is absorbed by expenses.

The third factor $\left(X_{3}\right)$ in model characterizes the relation of authorized capital to net assets of the company and represents an indicator of a share of authorized capital in net assets (Duk). This factor allows to reflect the level of a investment development of the organization and the level of financial risk for its creditors.

The size of the organization net assets characterizes existence of the assets which aren't burdened with obligations. The procedure of payments of net assets is defined by the Order of the Ministry of Finance of the Russian Federation of 28.08.2014 № 84n "About the statement of the Order of determination of cost of net assets", № 34299 registered in the Ministry of Justice of the Russian Federation of 14.10.2014 (further the Order № 84n) (The order of the Ministry of Finance of the Russian Federation from 28.08.2014).

This order of determination of net assets size is applied by joint-stock companies, limited liability companies, the state unitary enterprises, the municipal unitary enterprises, production cooperatives, housing accumulative cooperatives, economic partnership, and organizers of gamblings. Action of the Order № 84n on the credit organizations and joint-stock investment funds doesn't extend.

The cost of net assets is defined as a difference between the size of the assets of the organization accepted to calculation and size of the obligations of the organization accepted to calculation.

The assets accepted to calculation include all assets of the organization, except for receivables of founders (participants, shareholders, owners, members) on contributions (deposits) to authorized capital (an authorized capital, share fund, the depository capital), on payment of actions.

The obligations accepted to calculation include all obligations of the organization, except for the income of future periods recognized by the organization in connection with receiving the state help, and also in connection with gratuitous receiving property. 
Thus, calculation of cost of net assets for balance is made according to the following formula:

Net assets value $=\left[(\text { Non-current assets ( } p .1100 \text { balances) }+ \text { Current assets ( } p .1200 \text { balances) })^{*}\right]-$

- [(Long-term obligations ( $p .1400$ balances) + Short-term obligations ( $p .1500$ balances) -

- The income of future periods recognized by the organization in connection with receiving the state help, and also in connection with gratuitous receiving property (interpretation of p. 1530 balances)] (2)

*Excepting receivables of founders (participants, shareholders, owners, members) on contributions (deposits) to authorized capital (an authorized capital, share fund, the depository capital), on payment of actions.

Following the results of calculation of cost of net assets it is necessary to estimate its compliance to the norms and criteria established by the Federal law of 26.12.1995 to № 208-FZ (to an edition of 06.04.2015) "About joint-stock companies" (The federal law from 26.12.1995) and the Federal law of 08.02.1998 № 14-FZ (an edition of 06.04.2015) "About limited liability companies" (The federal law from 08.02.1998).

So, if upon termination of the second fiscal year or each next fiscal year the cost of net assets of joint-stock company appears less than its authorized capital, the board of directors (supervisory board) of society by preparation for annual general shareholder meeting is obliged to include the section on a condition of its net assets which has to contain in structure of the annual report of society:

- the indicators characterizing dynamics of change of cost of net assets and authorized capital of society in three last complete fiscal years including financial year, or if society exists less than three years, for each complete fiscal year;

- results of the analysis of the reasons and factors which, according to board of directors (supervisory board) of society, led to that the cost of net assets of society appeared less than its authorized capital;

- the list of measures for reduction of cost of net assets of society in compliance with the size of its authorized capital (Novoselov, 2012; Novoselova \& Akhmadov, 2012 \& Novoselova, Novoselov, 2015).

If the cost of net assets of joint-stock company remains less than its authorized capital upon termination of the fiscal year following after the second fiscal year or each next fiscal year upon termination of which the cost of net assets of society appeared less than its authorized capital society not later than in six months after the termination of the corresponding fiscal year is obliged to accept one of the following decisions:

1) about reduction of authorized capital of society up to the size which isn't exceeding the cost of its net assets;

2) about liquidation of society.

If the cost of net assets of joint-stock company appears less than its authorized capital more than for 25 percent upon termination of three, six, nine or twelve months of the fiscal year following after the second fiscal year or each next fiscal year upon termination of which the cost of net assets of society appeared less than its authorized capital society twice with frequency is obliged to place once a month in mass media in which data on the state registration of legal entities, the notice of depreciation of net assets of society are published (Magsumov, 2015).

The creditor of society if its rights of the requirement arose before publication of the notice of net assets depreciation, no later than 30 days from the date of the last publication of such notice has the right to demand from society of early execution of the corresponding obligation, and at impossibility of its early execution - the terminations of the obligation and compensation of the losses connected with it. The term of limitation period for an appeal to the court with this requirement makes six months from the date of the last publication of the notice of of net assets depreciation.

- The court has the right to refuse satisfaction of requirements of creditors in case society proves that:

- $\quad$ as a result of depreciation of its net assets the rights of creditors aren't violated;

- $\quad$ the providing provided for appropriate execution of the corresponding obligation is sufficient (The federal law from 26.12.1995).

If upon termination of the second fiscal year or each next fiscal year the cost of net assets appears less than a size of the minimum authorized capital, the firm not later than in six months after the termination of fiscal year is obliged to make the decision on the elimination.

Thus, the management has to control observance of the following inequality:

Net assets value $\geq$ Size of authorized capital

Proceeding from this ratio, $X_{3}$ factor entered into factorial model has to be less or is equal 1 .

Also the balancing coefficient a1, representing the revenue relation to the size of authorized capital of the interregional distribution grid company was entered into model:

( $a_{1}=$ Income / charter capital)

This coefficient characterize financial IDGC's activity and represents an turnover indicator of authorized capital (Ouk). It compensate the second and third factors to model, allowing to receive a final indicator of stability financial state of the company. 
Thus, the factorial model allows to estimate extent of influence of the approaches to accumulation of the market potential chosen by the interregional distribution grid company from a production, financial and investment activity and has the following appearance:

$$
P_{\text {aкm }}=K_{\text {aвm.мод }} \times P_{\text {прод.мод }} \times Д_{y \kappa} \times O_{\text {ук }}
$$

where $P_{\text {akm }}$ - assets profitability on net profit,

Kaem.nod- the modified autonomy coefficient,

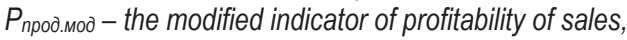

$Д_{y \kappa}-$ indicator of a share of authorized capital in net assets of the organization,

$\mathrm{O}_{\mathrm{yk}}-$ coefficient of turnover of authorized capital.

The company can maintain value of a resultant indicator of assets profitability in reasonable sizes by improving the production, rational price policy, attraction economically the justified long-term sources of financing the activity, increase in own capital due to additional issue of shares, the weighed dividend and investment policy.

The advantage of the offered factorial model is inclusion in it of indicators which calculation is made according to the published financial statements made under the Russian accounting standards (RAS).

If the reporting is made according to the International Financial Reporting Standards (IFRS), the modified model of factorial dependence (table 2) is used.

Table 2 - The modified factorial model of profitability of IDGC's assets

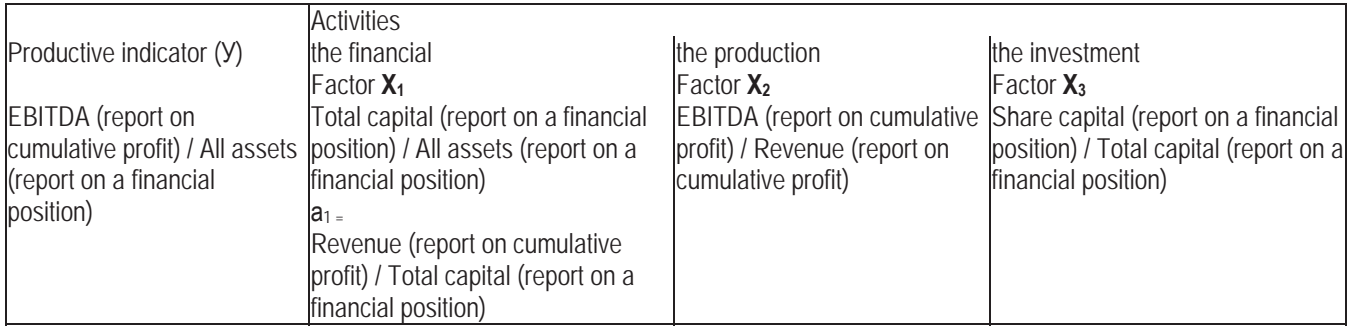

Indicator EBITDA (Earnings before Interest, Taxation, Depreciation and Amortization) characterizes the size of operating profit to a deduction of percent, taxes and depreciation.

On the basis of the reporting made according to RAS calculation of an indicator is possible EBITDA without specifications (6):

EBITDA = EBIT + Depreciation charges on material and intangible assets - asset revaluation =

$=$ Profit (loss) to the taxation (p. 2300) - Percent to payment (p. 2320) +

+ Depreciation charges on material and intangible assets - Revaluation of assets

and with specifications (7):

EBITDA = Profit (loss) to the taxation (p. 2300) + Percent to payment (p. 2330) - Interest receivable (p. 2320) + the Paid commissions on credit agreements and guarantees + Atypical expenses and single payments from p. 2350 the Other expenses - the Atypical income (from single transactions) from p. 2340 the Other income

+ Depreciation charges - Revaluation of assets

The modified model of factorial dependence has an appearance:

$R O A=E R \times P M \times E S \times E T$

where ROA - assets profitability on profit to a deduction of percent, taxes and depreciation,

ER - the modified autonomy coefficient,

PM - the modified indicator of profitability of sales on profit to a deduction of percent, taxes and depreciation,

ES - indicator of a share of the share capital in own capital of the organization,

ET - coefficient of turnover of the share capital.

The assessment of influence of factors in the offered models (5) and (9) can be carried out by means of receptions of the determined factorial analysis (methods of chain substitutions, absolute differences, relative differences, an integrated method, etc.). The way of chain substitutions on the basis of which the following models of analytical tables are offered is universal.

Changes of an integrated indicator and factors (on IDGC in general, and also on the societies operated by it) it is 
possible to investigate in the following form (tab. 3).

Table 3. The model for carrying out the factorial analysis of assets profitability of IDGC

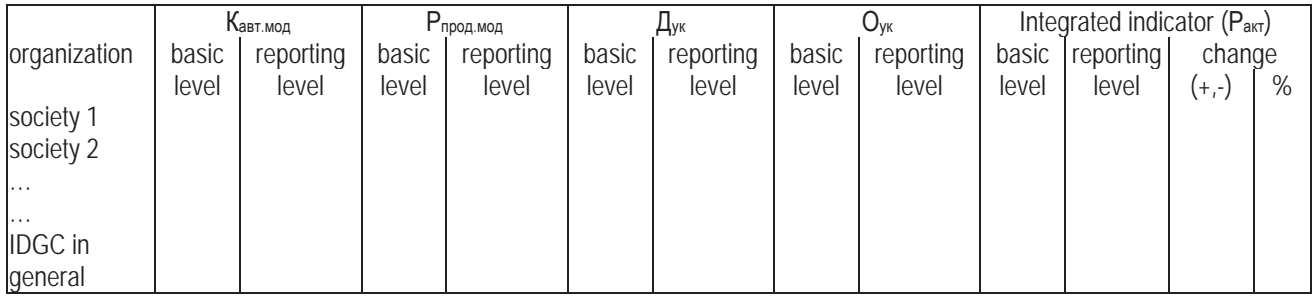

The model presented in tab. 6 gives the chance of carrying out the qualitative comparative analysis of the assets profitability and factors defining it how in general on IDGC, and in a section of separate business units that allows to reveal critical places (regions, the power enterprises) and time of their emergence. It is similarly possible to reveal concrete points of sharp change of indicators. After that the specific program of actions for alignment and improvement of a financial situation can be planned.

The following model of the analytical table (table 4) is developed for quantitative measurement of influence of the factors included in the offered factorial model of an assessment of assets profitability of IDGC with method of chain substitutions.

Table 4. Analysis of factorial model of assets profitability of IDGC with method of chain substitutions

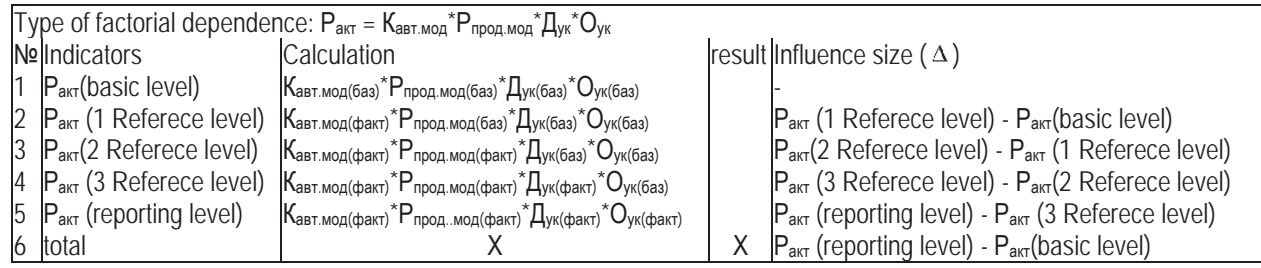

We will carry out the factorial analysis of assets profitability of "Interregional Distribution Grid Company of the North Caucasus" open joint stock company (JSC IDGC of the North Caucasus, IDGC of Northern Caucasus, JSC) and Chechen-Energo open joint stock company (the operated society). According to the 3-rd model offered in the tab., we will carry out the analysis of assets profitability of the studied organizations to table 5.

Table 5. Analysis of assets profitability of JSC IDGC of the North Caucasus and JSC Chechen-Energo

\begin{tabular}{|c|c|c|c|c|c|c|c|c|c|c|c|c|}
\hline \multirow{3}{*}{ organization } & \multicolumn{2}{|c|}{ Кавтмон } & \multicolumn{2}{|c|}{$\mathrm{P}_{\text {прод.мод }}$} & \multicolumn{2}{|c|}{$Д_{y \kappa}$} & \multicolumn{2}{|c|}{$\mathrm{O}_{y \mathrm{k}}$} & \multicolumn{4}{|c|}{ Integrated indicator $\left(\right.$ Ракт $\left._{1}\right)$} \\
\hline & & & & & & & & & & & chan & \\
\hline & & & & & 2010 & $\angle 014$ & & & & & $(+,-)$ & $\%$ \\
\hline & 029 & 0,800 & $-0,56$ & $-0,13$ & 0,0005 & 1,012 & 4019,61 & 0,356 & $-0,03$ & $-0,03$ & $-0,005$ & 1151 \\
\hline SC IDGC North Caucasus & 0,614 & 0,542 & 0,041 & $-0,12$ & 0,008 & 0,008 & 84,6 & 87,310 & 0,017 & $-0,04$ & $-0,06$ & -270 \\
\hline
\end{tabular}

In table 6 dynamics the assets of profitability and factorial indicators of JSC Chechen-Energo calculated in tab. 5 are shown.

Table 6 - Dynamics of the indicators included in factorial model on JSC Chechen-Energo (2013-2014)

\begin{tabular}{|c|c|c|c|c|c|}
\hline Year & $\begin{array}{c}\text { Modified coefficient of } \\
\text { autonomy }\end{array}$ & $\begin{array}{c}\text { Rentability of } \\
\text { sales }\end{array}$ & $\begin{array}{c}\text { The share of charter capital } \\
\text { in the net assets }\end{array}$ & $\begin{array}{c}\text { Capital } \\
\text { turnover }\end{array}$ & $\begin{array}{c}\text { Rentability of the assets on } \\
\text { the net profit }\end{array}$ \\
2013 & -0.680 & 0.021 & -2.570 & 5.110 & 0.187 \\
\hline
\end{tabular}


In table 7 dynamics of the indicators included in factorial model on JSC IDGC North Caucasus are shown.

Table 7 - Dynamics of the indicators included in factorial model on JSC IDGC North Caucasus

\begin{tabular}{|c|c|c|c|c|c|}
\hline Year & Modified coefficient of & Rentability of & The share of charter capital in & Capital & Rentability of the assets on the \\
net profit \\
2013 & autonomy & sales & the net assets & 84.600 & 0.017 \\
2014 & 0.017 & 0.017 & 0.017 & 87.310 & -0.046 \\
\hline
\end{tabular}

Thus, the indicator of the assets profitability calculated on the basis of net profit in 2013 at JSC Chechen-Energo was significantly lower, than at parent organization. Unprofitability of activity at the level of 3,3\% whereas profitability of activity of JSC IDGC North Caucasus was equal $1,7 \%$ was observed.

In 2014 negative dynamics of change of assets profitability of JSC Chechen-Energo remained, unprofitability of activity made $3,8 \%$. Efficiency of activity of JSC IDGC North Caucasus also significantly fell, the loss made $4,6 \%$ of the size of total assets of the organization.

We will estimate dynamics of the factors included in model. The first factor characterizing financial activity of branch (the relation of net assets to total assets) was positive and increased for the analyzed time period $(0,029$ in 2013 and 0,8 in 2014), and at parent organization this indicator corresponded to standard value $(0,614$ in 2013 and 0,542 in 2014).

Since the $X_{1}$ factor defines potential opportunity to influence financial policy of the company by changing structure and volume of own capital and assets, growth of value of this factor is a positive tendency (Novoselova \& Batchayev, 2013).

JSC Chechen-Energo had a negative the second factor characterizing operating activities (the modified coefficient of profitability of sales) and made in 2014-13,3\%. Unprofitability of sales of the organization in 2013 was at the level of $56,9 \%$.

Value of an indicator of profitability of sales of controlled society was significantly lower, than at parent organization. Profitability of sales of JSC IDGC North Caucasus for 31.12 .2013 made 4,1\%, and for 31.12 .2014 it is equal-12,1\% (net loss is received).

The third factor characterizing investment activity of the organization (the relation of authorized capital to net assets) at JSC Chechen-Energo made in 2013 is 0,005, and in 2014 the indicator significantly increased - to 1,012 (for the account of both positive dynamics both authorized capital, and net assets). At parent organization this indicator for the analyzed period didn't change and remained at 0,008.

The balancing coefficient characterizing a ratio of revenue and authorized capital at JSC Chechen-Energo had the most ambiguous tendency of change. At the expense of very low indicator of size of authorized capital (100 thousand rubles), the coefficient of turnover of authorized capital was equal in 2013 4019,61 turns. In 2014 there was a growth of authorized capital to the level of 5884192 thousand rubles that stabilized value of coefficient of turnover $(0,356$ turns). Turnover of authorized capital of JSC IDGC of the North Caucasus in 2013 was at the level of 84,6 turns, in 2014 the indicator increased to 87,3 turns.

We will carry out the factorial analysis of the offered model by method of chain substitutions according to JSC Chechen-Energo to table 8.

Table 8 - Analysis of factorial model of assets profitability of JSC Chechen-Energo with method of chain substitutions

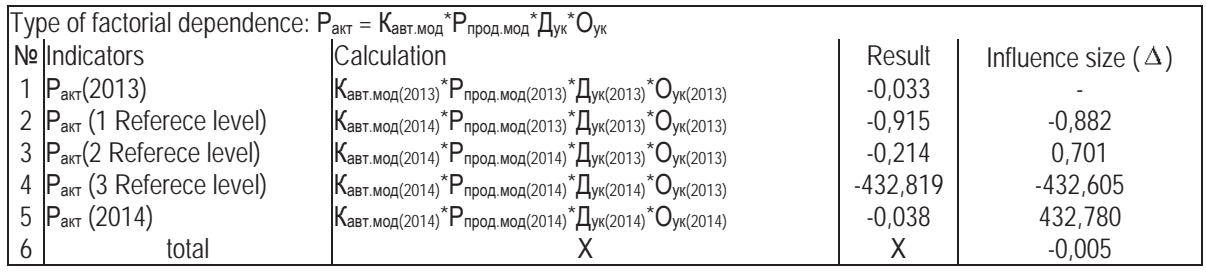

Thus, decrease in assets profitability of JSC Chechen-Energo by $0,5 \%$ was caused by influence of the following indicators:

- $\quad$ at the expense of the modified autonomy coefficient assets profitability decreased by $88,2 \%$; 
- due to growth of profitability of sales, assets profitability increased by $70,1 \%$;

- due to growth of a share of authorized capital in net assets, assets profitability decreased by $43260,5 \%$;

- due to change of turnover of authorized capital, assets profitability decreased by $43278 \%$.

We will carry out the factorial analysis of assets profitability of JSC IDGC North Caucasus with method of chain substitutions to table 9 .

Table 9 - Analysis of factorial model of assets profitability of JSC IDGC North Caucasus with method of chain substitutions

\begin{tabular}{|c|c|c|c|}
\hline \multicolumn{4}{|c|}{ Type of factorial dependence: $P_{\text {акт }}=K_{\text {авт.мод }}{ }^{*} P_{\text {прод.мод }}{ }^{*} Д_{у к}{ }^{*} \mathrm{O}_{\text {ук }}$} \\
\hline № Indicators & Calculation & result & Influence size $(\Delta)$ \\
\hline 1 Р Ркт(2013) & Кавт.мод(2013) ${ }^{*} \mathrm{P}_{\text {прод.мод(2013) }}{ }^{*} Д_{\text {ук(2013) }}{ }^{\star} \mathrm{O}_{\text {ук(2013) }}$ & 0,017 & - \\
\hline 2 Р Ркт (1 Referece level) & Кавт.мод(2014) ${ }^{*} \mathrm{P}_{\text {прод.мод(2013) }}{ }^{*} Д_{\text {ук(2013) }}{ }^{*} \mathrm{O}_{\text {ук(2013) }}$ & 0,015 & $-0,002$ \\
\hline 3 Р Ркт(2 Referece level) & $К_{\text {авт.мод(2014) }}{ }^{*} \mathrm{P}_{\text {прод.мод(2014) }}{ }^{*} Д_{\text {ук(2013) }}{ }^{*} \mathrm{O}_{\text {ук(2013) }}$ & $-0,044$ & $-0,059$ \\
\hline $4 P_{\text {акт (3 Referece level) }}$ & Кавт.мод(2014) $^{*} \mathrm{P}_{\text {прод.мод(2014) }}{ }^{*} Д_{\text {ук(2014) }}{ }^{*} \mathrm{O}_{\text {ук(2013) }}$ & $-0,044$ & 0 \\
\hline 5 P & Кавт.мод(2014) $^{*} \mathrm{P}_{\text {прод.мод(2014) }}{ }^{*} Д_{\text {ук(2014) }}{ }^{*} \mathrm{O}_{\text {ук(2014) }}$ & $-0,046$ & $-0,002$ \\
\hline 6 total & $x$ & $\mathrm{X}$ & $-0,063$ \\
\hline
\end{tabular}

Thus, decrease in assets profitability of JSC IDGC North Caucasus by $6,3 \%$ was caused by influence of the following indicators:

- due to decrease in the modified autonomy coefficient by $7,2 \%$, assets profitability I decreased by $0,2 \%$;

- due to decrease in profitability of sales by $16,2 \%$, assets profitability I fell to $5,9 \%$;

- the share of authorized capital in net assets of parent organization for the analyzed period didn't change thereof this factor had no impact on change of assets profitability;

- due to turnover of authorized capital assets profitability decreased by $0,2 \%$.

\section{Concluding Remarks}

Results of the carried-out factorial analysis revealed existence of problems in financial and economic activity as at JSC Chechen-Energo, and "IDGC the North Caucasus" in general. The main problems of controlled society were concentrated in the financial sphere (irrational structure of the capital of the organization), and also in the production sphere (low profitability of sales). At parent organization of a problem are concentrated in the production sphere (decrease in profitability of sales, negative size of net profit).

Thus, the practical importance of results of research consists in possibility of application of the offered factorial model in activity of the interregional distribution grid companies for increase of validity of adoption of administrative decisions.

\section{References}

The order of the Ministry of Finance of the Russian Federation from 28.08.2014g. № 84n "About the statement of the Order of determination of cost of net assets" (It is registered in the Ministry of Justice of the Russian Federation 14.10.2014g. № 34299).

The federal law from 26.12.1995g. № 208-FZ (an edition from 06.04.2015g.) "About joint-stock companies".

The federal law from 08.02.1998g. № 14-FZ (an edition from 06.04.2015g.) "About limited liability companies".

Novoselov, S.N. (2012) new settlers. Ecological business: essence, features, ways of development//Engineering bulletin of Don: electronic scientific magazine. № 4. Ch. 2.

Novoselova, N.N. \& Akhmadov M.-E.I. (2012) Ensuring reproduction development of regional economy taking into account system of factors of financial, investment, consumer and institutional character//the Engineering bulletin of Don: electronic magazine. № 1//http://www .ivdon.ru

Magsumov, T. A. (2014). Main approaches to the study of historical and educational process. Bylye Gody, 34(4), 720-726.

Magsumov, T. A. (2015). The additional professional training in the late russian empire. Bylye Gody, 36(2), 327-337.

Novoselova, N.N. \& Novoselov S.N. (2015) Institutsionalny imperatives and financial and information tools of development of branch systems//Business in the law. № 2. pp. 229-234.

Novoselova N.N. \& Batchayev S.M. (2013) Identification and an assessment of the "hidden" and "imaginary" assets and obligations//Black holes in the Russian legislation. № 5. pp. 134-137. 